\title{
QUALITY OF ORTHOPEDIC REHABILITATION OF PATIENTS WITH POST-TRAUMATIC DEFECTS OF THE UPPER JAW BY CHARACTERISTICS OF BIOCENOSIS OF THE ORAL CAVITY
}

10.36740/WLek202010106

\author{
Igor V. Yanishen, Olena L. Fedotova, Nataliia L. Khlystun, Olena 0. Berezhna, Roman V. Kuznetsov \\ KHARKIV NATIONAL MEDICAL UNIVERSITY, KHARKIV, UKRAINE
}

\begin{abstract}
The aim of the research was to study the dynamics of the microbiota's features of oral mucosal membrane during orthopedic rehabilitation of patients with removable dentures which has an obturating part with two-layer bases.

Materials and methods: To achieve this goal, our bacteriological examination of oral cavity mucosa was performed for 25 patients with partial adentia of the upper jaw and defect of hard palate and alveolar process.

Results and conclusions: Of the conducted studies indicate significant shifts in the qualitative and quantitative composition of microbiocenosis in the oral cavity in patients with partial adenia of the upper jaw and a defect of hard palate and alveolar process due to representatives of moraksel, enterobacteria (representatives of the kinds Klebsiella and $E$. coli). The comparing of frequency of extraction and the density of microbial colonization showed us the persistence in biotope of representatives near 13 kinds of bacteria and yeast-like fungi of the kind Candida in averages from $\lg (2,5 \pm 0,19)$ to $\lg (5,4 \pm 0,17) \mathrm{CFU} / \mathrm{g}$.

For patients who have been made a two-layered basis, materials of which are based on carboxymethylcellulose and polyvinialacetate in the period of adaptation to removable dentures, showed us that the detection of 5 component associations at 30 days was reduced by 2 times $(X 2=5,991 ; v=2 ; p<0,05)$. The frequency of removal and density of microbial colonization of the experimental group did not differ statistically. Among patients in the control group, the microbial colonization density increased for Enterococcus spp, for Klebsiella spp and for Candida spp. Yeast-like fungi. A significant decrease in the microbial density of the resident microflora was 1.4 times for Neisseria spp, 1.6 times for Lactobacillus spp $(\mathrm{p}<0,05)$.
\end{abstract}

KEY WORDS: microecology, two-layer basis, removable dentures, obturating part, mucous membrane of oral cavity

Wiad Lek. 2020;73(10):2138-2143

\section{INTRODUCTION}

About 700-1000 species of various microorganisms have been identified among representatives of oral microbiocenosis, their identification and quantification are quite a challenge [1]. The oral cavity is a complex ecological system in which external factors interact with the internal and are in dynamic equilibrium.

However, the variability of microflora with age, because the oral cavity differs favorable conditions for its reproduction $[2,3]$. Bacterial colonization is facilitated by optimal temperature and humidity, the presence of a slightly alkaline environment, different in structure of tissues and food residues.

Under the influence of various endogenous and exogenous factors, qualitative and quantitative changes in the microflora can occur, which contribute to the formation of dysbiosis. Dysbiotic condition of the oral cavity can leads to exacerbation or chronic course of stomatitis, ulcerative gingivitis, periodontitis and other dental diseases $[4,5]$.

Removable plastic dentures instigate violation of the microecology of the oral cavity $[6,7]$. The fact of the direct dependence of the rate of formation of microbial plaque on the prosthesis material was also established $[8,9]$. Es- pecially colonization of biotopes increases with the use of acrylic materials having a certain degree of porosity [10].

High level of microbial colonization is established both on the mucous membrane of the prosthetic area and on the surface of the prosthesis, analyzing the results of the study. The need to improve the quality of prosthetics by using more inert base materials is proved [11]. The diversity of the spectrum of microorganisms and the aggressiveness of the inflammatory changes provoked by local and general character confirm the special importance of studies of the microbial «scenery» of the mouth $[12,13,14]$.

The development and implementation of effective methods of prevention and treatment of oral microenvironment's disorders, especially in dental prosthetics, are extremely important and necessary for practical health care in modern conditions $[15,17]$. Therefore, the role of oral biocenosis in the formation of pathological processes in the orthopedic treatment of patients with upper jaw's post-traumatic defects requires further study and can be used as an additional criterion for determination the effectiveness of corrective therapy.

The use of different liners between the prosthesis base and the mucous membrane should be considered the 


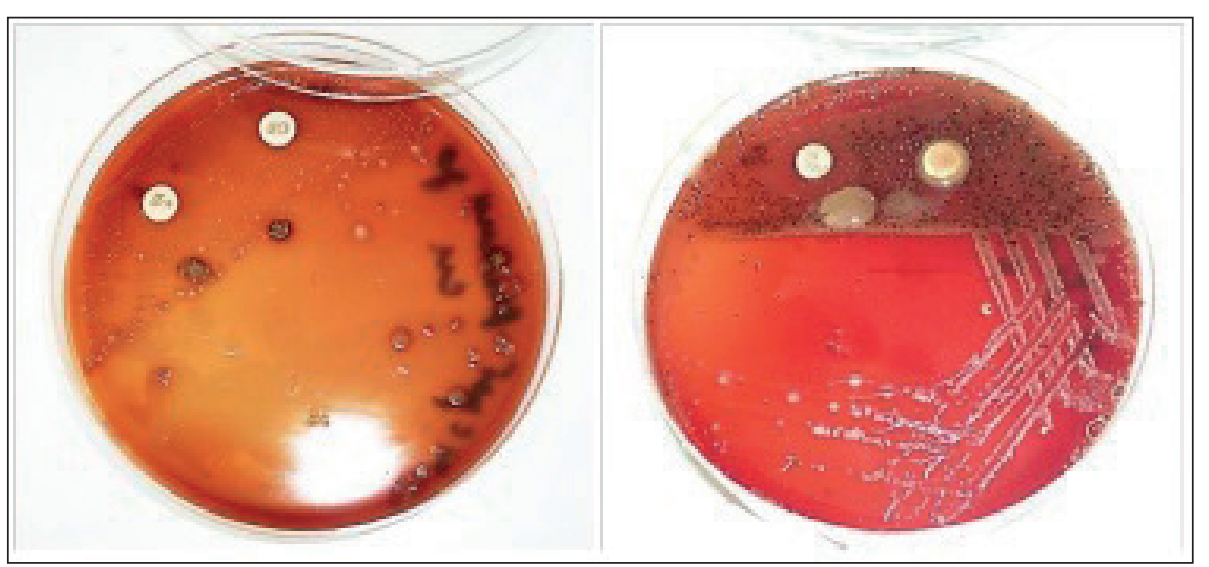

Fig. 1. Identification of extracted microbial cultures most promising which improve fixation and eliminate incidental effects - irritation, hypersensitivity. At the same time, the term of adaptation to plate prostheses is significantly reduced.

\section{THE AIM}

The purpose of the research is to study the dynamics of the representatives of the oral mucosa's microbiota during prosthetic rehabilitation of patients with removable dentures which has an obturating part with two-layer bases.

\section{MATERIALS AND METHODS}

The study was conducted at the Department of Orthopedic Dentistry, University Dental Center, Kharkiv National Medical University.

Deontological aspects are resolved within the framework of the legislation in force in Ukraine, the Law of Ukraine "On Medicines", 1996, Art. 7, 8, 12, principles of ICH GCP (2008), order of the Ministry of Health of Ukraine No. 690 of 23.09.2009 "On approval of the Rules for clinical trials and expertise of materials of clinical trials and model regulations on the ethics commission", as amended; World Health Association Declaration of Helsinki. The study was performed with minimal psychological loss for patients. Patients were fully informed about the purpose and methods of the study, the potential gains and risks, and the possible discomfort with the diagnosis and treatment. All ethical requirements for maintaining the confidentiality of the information received during the study are fulfilled. The work was reviewed and approved by the Bioethics Commission of the KhNMU of the Ministry of Health of Ukraine.

To achieve this goal, a bacteriological study of the oral mucosa was performed on 25 patients. Clinical patient groups were formed by the following criteria: the main group consisted of 13 patients with partial adentia of the upper jaw and defect of the hard palate and alveolar process (groups 1A and 1B by V.Y. Kurlandsky) which made two-layer removable prostheses with a obturating part using "PM-SN" JSC "Stoma". The control group consisted of 12 patients with partial adentia of the upper jaw and defect of the hard palate and alveolar process (groups 1A and
$1 \mathrm{~B}$ according to V.Y.Kurlandsky), which made obturating removable prostheses by the usual method.

Material collection, transportation and bacteriological examination were carried out in accordance with current regulatory documents by conventional methods [16]. Removable prosthesis and oral cavity were thoroughly rinsed with physiological solution for remove food's residue. The material was collected 20 minutes after mouthwash with physiological solution: before the prosthesis, after a week and after a month of prosthesis.

Material from the oral mucosa was removed with a cotton swab, which is in a tube with a Stuart transport medium.

The crops were made on 5\% blood agar, Endo medium, enterococar, yolk-salt agar to extract aerobic and optional anaerobic bacteria. Saburo medium was used for yeast and molds. The crops were incubated at $37^{\circ} \mathrm{C}$ from 24 till 120 hours under aerobic conditions, depending on the group of microorganisms tested (Fig. 1).

The identification of the extracted bacterial cultures was carried out on the basis of morphological, cultural, biochemical characteristics according to the «The determinant of the bacteria is Berdy», 1997; identification of fungal strains - according to the "The determinant of pathogenic and conditionally pathogenic fungi», 2001 by standard methods.

The quantity of microorganisms was determined by counting colony forming units in $1 \mathrm{~g}$ of material and expressed in decimal logs (lg CFU/g).

Formation of the database on the results of the research was carried out in Microsoft Excel, 2007. Statistical processing of the research results was carried out using the software package Statistica v. 8.0. The arithmetic mean of the quantitative indicators presented in the text $(\mathrm{M} \pm \mathrm{m})$ was calculated, where " $\mathrm{M}$ " is the sample mean and " $\mathrm{m}$ " is the error of the mean. The results of the description of qualitative indicators (frequency of withdrawal) were expressed in percentage. In all statistical analysis procedures, the achieved significance level (p) was calculated, with the critical significance level in this study assumed to be 0.05 . The hypothesis of the equality of the general averages in the two groups compared was tested using the nonparametric Wilcoxon-Mann-Whitney criterion for independent samples, and the percentages using the $\chi$-square criterion $[18,19]$. 
Table 1. Quantitative characterization of microbial associations isolated from the alveolar ridge in the examined patients of the experimental and control group depending on the time of adaptation to the removable prosthesis

\begin{tabular}{|c|c|c|c|c|c|}
\hline \multirow{2}{*}{$\begin{array}{l}\text { Groups of patients } \\
\text { examined }\end{array}$} & \multirow{2}{*}{$\begin{array}{l}\text { Subgroups of patients } \\
\text { examined }\end{array}$} & \multicolumn{4}{|c|}{ The frequency of removal of microbial associations, \% } \\
\hline & & 2-components & 3-components & 4- components & 5-components \\
\hline \multirow{3}{*}{$\begin{array}{l}\text { Patients with } \\
\text { a two-layer basis } \\
n=13\end{array}$} & $\begin{array}{l}\text { before putting the } \\
\text { prosthesis }\end{array}$ & 26,1 & 34,8 & 21,7 & 17,4 \\
\hline & 7 days & 30,4 & 26,1 & 30,4 & 13,1 \\
\hline & 30 days & 34,8 & 30,4 & 26,1 & 8,7 \\
\hline \multirow{3}{*}{$\begin{array}{l}\text { Control group, } \\
\mathrm{n}=12\end{array}$} & $\begin{array}{l}\text { before putting the } \\
\text { prosthesis }\end{array}$ & 25,0 & 33,3 & 25,0 & 16,7 \\
\hline & 7 days & 16,7 & 25,0 & 41,6 & 16,7 \\
\hline & 30 days & 8,3 & 16,7 & 50,0 & 25,0 \\
\hline
\end{tabular}

Table 2. Characterization of oral microbiocenosis in the adaptation period to removable prosthesis.

\begin{tabular}{|c|c|c|c|c|c|c|c|}
\hline \multirow{3}{*}{$\begin{array}{c}\text { Removal } \\
\text { frequency (\%) }\end{array}$} & \multirow{3}{*}{$\begin{array}{l}\text { Representatives of aerobic and } \\
\text { optional anaerobic microflora }\end{array}$} & \multicolumn{3}{|c|}{ Experimental group, $n=13$} & \multicolumn{3}{|c|}{ Control group, $n=12$} \\
\hline & & $\begin{array}{l}\text { before putting } \\
\text { the prosthesis }\end{array}$ & 7 days & 30 days & $\begin{array}{l}\text { before putting } \\
\text { the prosthesis }\end{array}$ & 7 days & 30 days \\
\hline & & \multicolumn{6}{|c|}{ The number of strains removed (\%) } \\
\hline$>50,0 \%$ & $\begin{array}{l}\text { Streptococcus spp with } \\
a ́ \text {-hemolytic properties }\end{array}$ & 73,9 & 69,6 & 69,6 & 66,7 & 58,3 & 66,7 \\
\hline \multirow{2}{*}{$\begin{array}{c}30,1- \\
50,0 \%\end{array}$} & Corynebacterium spp & 39,1 & 39,1 & 39,1 & 50,0 & 41,6 & 50,0 \\
\hline & Neisseria spp & 43,5 & 7,8 & 43,5 & 41,6 & 33,3 & 41,6 \\
\hline \multirow{6}{*}{$\begin{array}{c}20,1- \\
30,0 \%\end{array}$} & Lactobacillus spp & 26,1 & 26,1 & 26,1 & 33,3 & 33,3 & 25,0 \\
\hline & S. pyogenes & 21,7 & 21,7 & 21,7 & 25,0 & 33,3 & 33,3 \\
\hline & Micrococcus sp & 21,7 & 26,1 & 21,7 & 25,0 & 25,0 & 25,0 \\
\hline & Moraxella spp & 21,7 & 21,7 & 21,7 & 33,3 & 33,3 & 33,3 \\
\hline & E. coli & 21,7 & 21,7 & 21,7 & 25,0 & 25,0 & 25,0 \\
\hline & M. morganii & 21,7 & 26,1 & 26,1 & 33,3 & 33,3 & 33,3 \\
\hline \multirow{5}{*}{$\begin{array}{c}10,0- \\
20,0 \%\end{array}$} & Haemophillus spp & 17,4 & 17,4 & 13,1 & 16,7 & 16,7 & 16,7 \\
\hline & Enterococcus spp & 13,1 & 17,4 & 13,1 & 8,3 & 8,3 & 16,7 \\
\hline & Klebsiella spp & 13,1 & 13,1 & 13,1 & 8,3 & 8,3 & 8,3 \\
\hline & Candida spp & 17,4 & 17,4 & 13,1 & 16,7 & 16,7 & 16,7 \\
\hline & Staphylococcus spp & 13,1 & 13,1 & 13,1 & 8,3 & 8,3 & 8,3 \\
\hline
\end{tabular}

Note: ${ }^{*}$ the difference is significant between the indicators $(p<0,05)$.

\section{RESULTS AND DISCUSSION}

Microbiological studies included the determination of qualitative and quantitative composition of biocenosis. The microflora of patients with partial adentation of the upper jaw and defect of the hard palate and alveolar process were found to consist of associations of yeast fungi with 2-5 representatives of the microbial world. (Table 1).

No significant differences were found between the persistence of microbial associations of the oral mucosa of the test and control groups of individuals prior to use of the removable prosthesis during the study..

The deletion of 3-component microbial associations in patients of the experimental group was found to decrease 1.3 times on the 7th day of the study, and the deletion of 4-component associations among the experimental group on the 7 th day was 1.4 times more frequent. For patients with a two-layer basis, the frequency of detection of 2-component microbial associative on the 30th day of the study was more than 1.3 times more frequent. Detection of 5 component associations on the 30th day decreased by 2 -fold $(\chi 2=5,991 ; \nu=2 ; \mathrm{p}<0.05)$. Instead, the dynamics of the distribution of 4 -component microbial associations in the oral cavity after a week of adaptation to the prosthesis was 1.6 times more frequent in patients of the control group, 5-component associations remained at the initial level. However, after 30 days the distribution of 4 component microbial associations among the patients of the control group was 2 times more frequent, than the initial indicators, the percentage of 5 component associations was 1.5 times more frequent $(\chi 2=5,991 ; v=2 ; p<0.05)$.

The structure of microbiocenoses of the oral mucosa of the examined patients is represented by 13 bacterial species and yeast-like fungi of the genus Candida in average quantities from $\lg (2.5 \pm 0.19)$ to $\lg (5.4 \pm 0.17) \mathrm{CFU} / \mathrm{g}$ (Tables 2, 3 ). 
Table 3. The density of microbial colonization of the oral cavity in the adaptation period to the removable prosthesis

\begin{tabular}{|c|c|c|c|c|c|c|c|}
\hline \multirow{2}{*}{$\mathrm{p} / \mathrm{n}$} & \multirow{2}{*}{$\begin{array}{c}\text { Representatives of aerobic } \\
\text { and optional anaerobic } \\
\text { microflora }\end{array}$} & \multicolumn{3}{|c|}{$\begin{array}{l}\text { Experimental group, } \mathrm{n}=13 \\
\text { (Ig CFU/g) }\end{array}$} & \multicolumn{3}{|c|}{$\begin{array}{l}\text { Control group, } \mathrm{n}=12 \\
\text { (Ig CFU/g) }\end{array}$} \\
\hline & & $\begin{array}{l}\text { before putting the } \\
\text { prosthesis }\end{array}$ & 7 days & 30 days & $\begin{array}{l}\text { before putting } \\
\text { the prosthesis }\end{array}$ & 7 days & 30 days \\
\hline 1 & $\begin{array}{l}\text { Streptococcus spp with } \\
\text { á-hemolytic properties }\end{array}$ & $4,6 \pm 0,15$ & $4,5 \pm 0,19$ & $4,8 \pm 0,21$ & $4,3 \pm 0,18$ & $3,8 \pm 0,15$ & $4,2 \pm 0,2$ \\
\hline 2 & Corynebacterium spp & $4,2 \pm 0,26$ & $4,1 \pm 0,2$ & $3,9 \pm 0,18$ & $4,3 \pm 0,1$ & $3,8 \pm 0,16$ & $3,6 \pm 0,11$ \\
\hline 3 & Neisseria spp & $5,2 \pm 0,22$ & $5,0 \pm 0,12$ & $4,9 \pm 0,1$ & $5,1 \pm 0,14$ & $4,6 \pm 0,1$ & $3,6 \pm 0,18^{*}$ \\
\hline 4 & Lactobacillus spp & $3,4 \pm 0,17$ & $3,2 \pm 0,1$ & $3,2 \pm 0,25$ & $3,6 \pm 0,11$ & $2,7 \pm 0,12$ & $2,3 \pm 0,18^{*}$ \\
\hline 5 & S. pyogenes & $3,2 \pm 0,29$ & $3,6 \pm 0,2$ & $3,4 \pm 0,18$ & $3,3 \pm 0,2$ & $3,8 \pm 0,12$ & $4,0 \pm 0,18$ \\
\hline 6 & Micrococcus sp & $3,2 \pm 0,2$ & $3,5 \pm 0,1$ & $3,8 \pm 0,09$ & $3,3 \pm 0,24$ & $3,8 \pm 0,19$ & $4,1 \pm 0,23$ \\
\hline 7 & Moraxella spp & $4,2 \pm 0,21$ & $4,6 \pm 0,25$ & $4,8 \pm 0,11$ & $4,3 \pm 0,2$ & $4,8 \pm 0,27$ & $5,4 \pm 0,17$ \\
\hline 8 & E. coli & $3,4 \pm 0,1$ & $3,2 \pm 0,2$ & $3,4 \pm 0,09$ & $3,3 \pm 0,22$ & $3,9 \pm 0,1$ & $4,1 \pm 0,09$ \\
\hline 9 & M. morganii & $3,0 \pm 0,13$ & $3,0 \pm 0,1$ & $2,7 \pm 0,2$ & $3,1 \pm 0,17$ & $3,2 \pm 0,1$ & $3,7 \pm 0,14$ \\
\hline 10 & Haemophillus spp & $3,6 \pm 0,19$ & $3,8 \pm 0,1$ & $3,8 \pm 0,22$ & $3,3 \pm 0,1$ & $3,8 \pm 0,14$ & $3,7 \pm 0,1$ \\
\hline 11 & Enterococcus spp & $2,5 \pm 0,19$ & $2,7 \pm 0,1$ & $3,0 \pm 0,21$ & $2,6 \pm 0,1$ & $3,1 \pm 0,12$ & $4,0 \pm 0,1^{*}$ \\
\hline 12 & Klebsiella spp & $2,8 \pm 0,15$ & $3,0 \pm 0,11$ & $3,2 \pm 0,13$ & $2,5 \pm 0,1$ & $3,0 \pm 0,13$ & $3,6 \pm 0,18^{*}$ \\
\hline 13 & Staphylococcus spp & $4,1 \pm 0,23$ & $4,0 \pm 0,2$ & $3,8 \pm 0,11$ & $4,2 \pm 0,09$ & $3,7 \pm 0,09$ & $3,5 \pm 0,16$ \\
\hline 14 & Candida spp & $3,1 \pm 0,09$ & $3,3 \pm 0,1$ & $3,6 \pm 0,2$ & $3,0 \pm 0,1$ & $3,7 \pm 0,19$ & $4,7 \pm 0,1^{*}$ \\
\hline
\end{tabular}

Note: * the difference is significant between the indicators $(p<0,05)$.

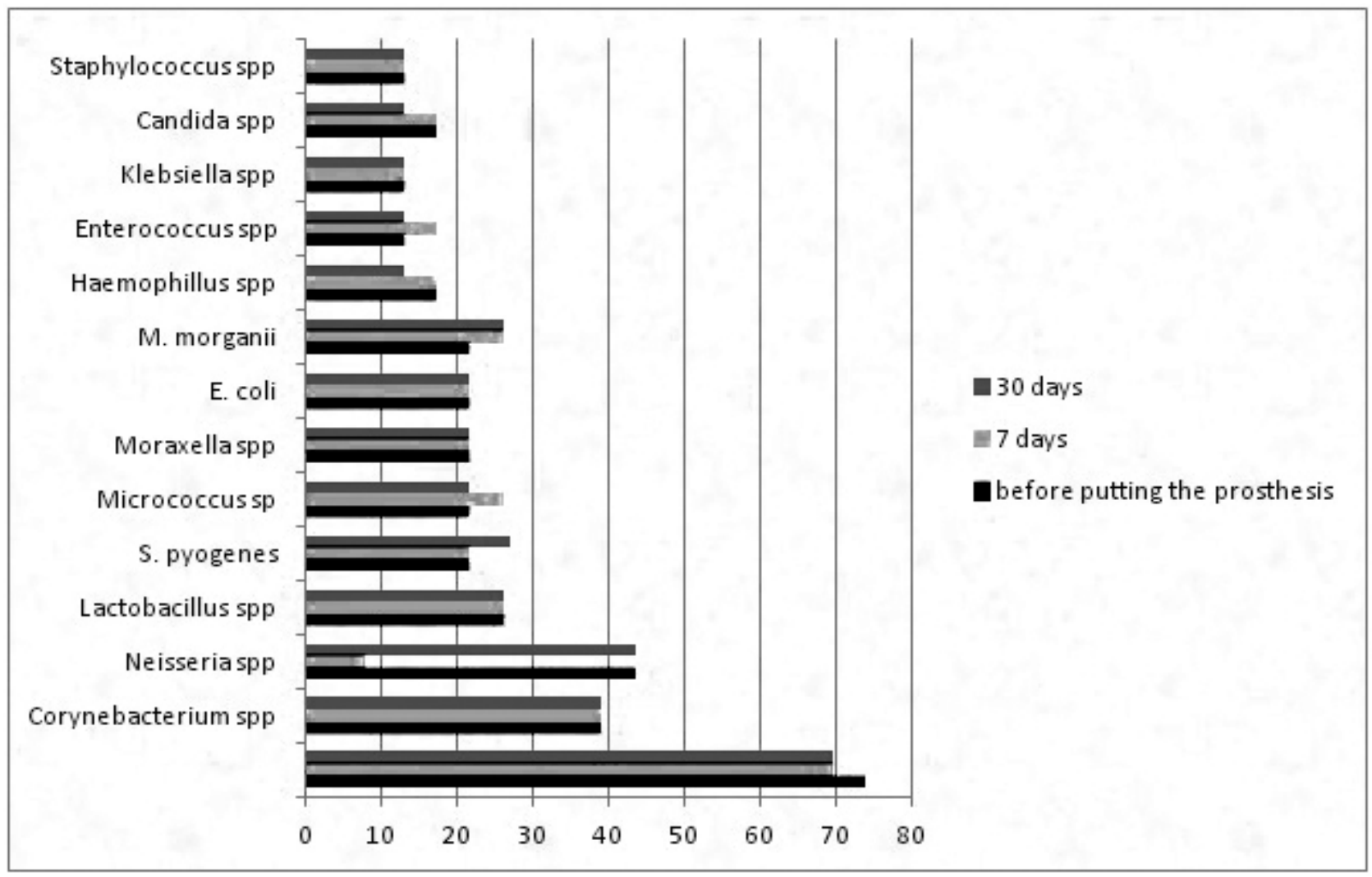

Fig. 2. Characterization of oral microbiocenosis in the adaptation period to the removable prosthesis.

In addition, an expansion of the species composition of microbiocenosis of the oral mucosa was established, due to representatives of moroccelles, enterobacteria (representatives of Klebsiella and E. coli species), as well as fungi
Candida spp. Against this background, a decrease in the frequency of extraction of representatives of resident microflora (neisseria, corynebacteria, lactobacilli) inherent in this biotope is normal (Figs. 2, 3). 


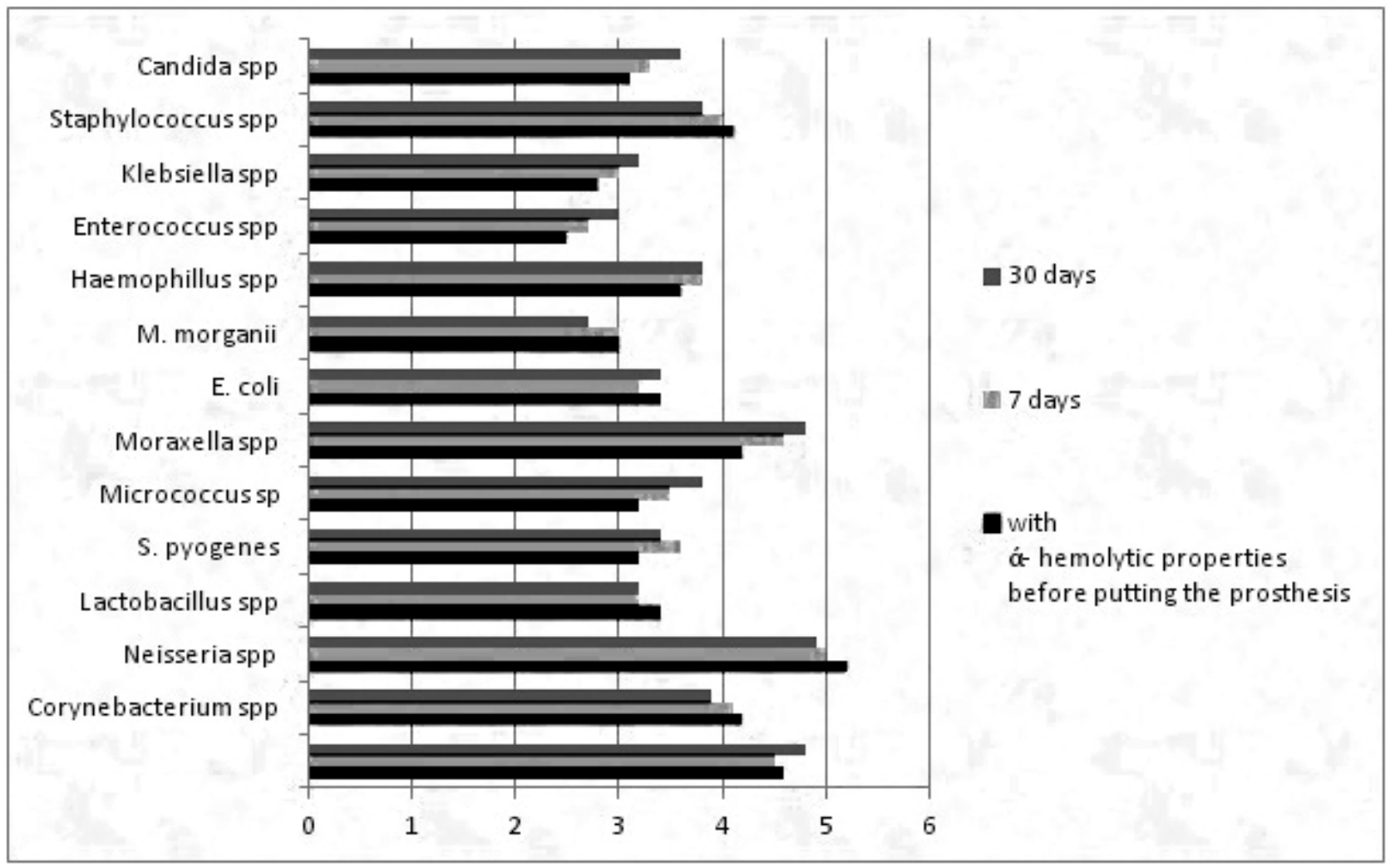

Fig. 3. The density of microbial colonization of the oral cavity in the adaptation period to the removable prosthesis

A primary examination of the alveolar crest microflora in patients in both groups showed a high level of microbial contamination.

When using a two-layer basis, the frequency of extraction and density of microbial colonization was not statistically different.

Instead, the microbial population density in the control group increased 1.5-fold for Enterococcus spp, 1.4-fold for Klebsiella spp, and 1.6-fold for the yeast-like fungus Candida spp. A significant decrease in the microbial density of representatives of resident microflora was found 1.4 times for Neisseria spp, 1.6 times for Lactobacillus spp $(\mathrm{p}<0.05)$.

\section{CONCLUSIONS}

The results of the studies indicate significant shifts in the qualitative and quantitative composition of oral microbiocenosis in patients with partial adentia of the upper jaw and defect of the hard palate and alveolar process due to representatives of moroxel, enterobacteriaceae (representatives of the genera Klebsiella and E. coli). Comparison of the frequency of extraction and the density of microbial colonization showed the persistence in the specified biotope of representatives of 13 kings of bacteria and yeast-like fungi of the king Candida in average quantities from $\lg (2.5 \pm 0.19)$ to $\lg (5.4 \pm 0.17) \mathrm{CFU} / \mathrm{g}$.

For patients treated with a two-layer base based on carboxymethylcellulose and polyvinyl acetate, during the adaptation to the removable prosthesis, there was a 2 -fold decrease in the detection of 5 component associations on the 30th day $\left(\chi^{2}=5,991 ; v=2 ; p<0,05\right)$. The frequency of extraction and the density of microbial colonization of the experimental group was not statistically different.

The microbial colonization density for Enterococcus spp, for Klebsiella spp and for yeast fungi Candida spp increased in the control group. A significant decrease in the microbial density of representatives of resident microflora was found 1.4 times for Neisseria spp, 1.6 times for Lactobacillus spp $(\mathrm{p}<0.05)$.

The revealed microbiological features in patients with adentia dictate the need to include a scheme for the correction of oral microbiocenosis of patients with partial adentia of the upper jaw and defect of the hard palate and alveolar process of the means with directed anti-inflammatory action and ensure the restoration and storage of normal biocenosis of the specified biotope.

Prospects for further research. The study of the dynamics of the representatives of the microbiota of the oral mucosa allows to assess the level of influence of changes in microecology on the tissues of the prosthetic area, and therefore further studies will be directed to the search for improving the chewing efficiency of patients with partial adentia of the upper jaw and defect of the hard palate and alveolar process for improving their quality of life.

\section{REFERENCES}

1. Zorina O.A., Kulakov A.A., Grudianov A.I. Mikrobiotsenoz polosti rta v norme i pri vospalitel'nyh zabolevaniiah parodonta.Stomatologiia. 2016;1:73-74. (in Ukrainian). 
2. Zaichenko 0.V. Vliianie biodestruktsii siemnyh plastinochnyh protezov iz razlichnyh akrilovyh plastmass na tkani rotovoi polosti [dissertation]. Moskva;2011.122 p. (in Russian).

3. Gavrilova 0.A., Chervinec Ju.V. Vozrastnye izmeneniia mikrobiotsenoza smeshannojsliuny inaletas spoverhnostizubov pri dekompensirovannom techenii karioznogo.Institut stomatologii.2009;1:80-81. (in Ukrainian).

4. Ivanova L.A. Korrekciia mikrobnogo sostava polosti rta pri disbioze. Institut stomatologii.2011;1:100-101. (in Ukrainian).

5. Yanishen I.V., Krychka N.V., Diudina I.L. et al. Assessment of anatomical and topographical individual characteristics of masticatory system in patients with complete adentium. British Medical Bulletin. 2017;1(2):806-813.

6. Yanishen I.V., Biryukova M.M., Diudina I.L. et al. Employment of functional tests in multivariable modeling of plastic dentures in patients with complete absence of teeth. Medical Education. 2017;6:1794-1499.

7. Zaichenko 0.V. Ocenka kolonizacii akrilovyh plastmass, ispol'zuemyh pri zubnom protezirovanii uslovno-patogennymi mikroorganizmami v eksperimente in vitro. Rossiiskii stomatologicheskii zhurnal. 2011;3:1921. (in Russian).

8. Vallittu P.K. Interpenetrating polymer networks (IPNS) in dental polymers and composites. J Adhes Sci Technol. 2014; 23: 961-972.

9. Yoshii E. Cytoxic effects of acrylates and methacrylates: relationship of monomer structure and cytotoxicity. J Biomed Mater Res.2016;37:517-524.

10. Kanivell M., Lopec Zh.L., TerezaV. Etal. Analiz bakteriostaticheskih svoistv razlichnyh materialov, ispol'zuemyh v stomatologii. Predvaritel'noe soobshhenie. Stomatologiia. 2017;3:26-30. (in Ukrainian).

11. Safarov A.M. Sostoianie slizistoi obolochki proteznogo lozha pri siemnom protezirovanii. Vestnik stomatologii.2017;2:121-123. (in Ukrainian).

12. Bondarenko V.M., Agapova 0.V., Vinogradov N.A. Rol' bakterial'noi proteazy, degradiruiushhii sekretornyi immunoglobulin A, v persistencii klebsiell. Mikrobiologiia. 2000;4:12-16. (in Russian).

13. Sysoev N.P., Polishhuk L.F. Mikroflora polosti rta pri pol'zovanii siemnymi plastinochnymi protezami. Stomatologiia. 2010;5:78-80. (in Ukrainian).

14. Kraft J., Hanck H., Neidermeir W. Effect of denture adhesives on growth of Candida species. Dtsch. Zahnaztl. Z. 2014;11:885- 887.

15. Yanishen I., Diudina I., Krychka N. et al. Experimental justification of a method-of-choice to protect the receptor apparatus of the teeth, supporting a non-removable design denture. Georgian medical news. 2019; 1:36-39.

16. Labunets V.A., Morozov .I.E, Novickii V.B. et al. Metody podgotovki tkanei proteznogo lozha k protezirovaniiu siemnymi plastinochnymi protezami. Vestnik stomatologii. 2016;1:62-64. (in Ukrainian).
17. Guidelines for the use of standardized microbiological (bacteriological) methods in clinical diagnostic laboratories. Application number 1 to the order of the USSR Ministry of Health number 535 of 22 April 2005. 45 p.

18. Lapach S.N., Chubenko A.V., Babich P.N. Statistical methods in biomedical research using Excel. K., "MORION". 2001:408 p.

19. Glantz S. Biomedical Statistics. M: Practice.2008:459 p.

The study is a fragment of the comprehensive research program of the Kharkiv National Medical University, Ministry of Health of Ukraine, Department of Orthopedic Dentistry "Character, structure and treatment of major dental diseases" (№ state registration 0116U004975; 2016-2018), in particular the author's scientific qualification work.

\section{ORCID and contributioship:}

Igor V. Yanishen: 0000-0003-4278-5355 ${ }^{\mathrm{E}, \mathrm{F}}$

Olena L. Fedotova: 0000-0001-9421-9262 B,D

Nataliia L. Khlystun: 0000-0001-6943-1835 ${ }^{A, B}$

Olena O.Berezhna: 0000-0003-4221-4608 ${ }^{\mathrm{C}}$

Roman V.Kuznetsov: 0000-0002-0314-5825 ${ }^{B}$

\section{Conflict of interest:}

The Authors declare no conflict of interest.

\section{CORRESPONDING AUTHOR Olena L. Fedotova \\ Department of orthopedic dentistry, Kharkiv National Medical University, Kharkiv, Ukraine tel: +380981232989 \\ e-mail:helennochka@i.ua}

Received: 15.04 .2020

Accepted: 27.08 .2020
A - Work concept and design, B - Data collection and analysis, C - Responsibility for statistical analysis, D-Writing the article, $\mathbf{E}$-Critical review, $\mathbf{F}$ - Final approval of the article 